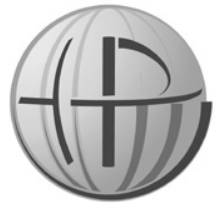

Horyzonty Polityki 2021, Vol. 12, No 40
JoANNA NiżNiK

http://orcid.org/0000-0003-3124-6663 Uniwersytet Ekonomiczny w Krakowie niznikj@uek.krakow.pl

DOI: 10.35765/HP.2132

\title{
Wpływ COVID-19 na systemy ochrony zdrowia w Czechach i Polsce
}

\begin{abstract}
Streszczenie
CEL NAUKOWY: Celem artykułu jest przedstawienie zmian w funkcjonowaniu systemów ochrony zdrowia w Polsce i w Czechach wywołanych COVID-19 oraz wskazanie na organizacyjne i finansowe wyzwania oraz skutki, którym musiały one sprostać.
\end{abstract}

PROBLEM I METODY BADAWCZE: Do realizacji celu pracy wykorzystano metody badawcze opierające się na rozumowaniu indukcyjnym związane ze studiami literatury przedmiotu, raportami zdrowotnymi, kwerendą zasobów Internetu oraz dostępnych baz danych.

PROCES WYWODU: Na podstawie informacji zawartych w wymienionych źródłach zrealizowano badania wtórne obejmujące pogłębioną analizę najważniejszych działań podejmowanych w badanych państwach w związku z pandemią COVID-19, zwracając szczególną uwagę na ich organizacyjne i finansowe skutki. Tłem rozważań stały się informacje dotyczące sytuacji epidemiologicznej i zdrowotnej.

WYNIKI ANALIZY NAUKOWEJ: Podstawowym wynikiem analizy jest ukazanie zmian zachodzących pod wpływem COVID-19 w systemach zdrowotnych badanych krajów.

WNIOSKI, INNOWACJE, REKOMENDACJE: Ostateczne wnioski i rekomendacje związane są z określeniem wyzwań dla systemów zdrowotnych na następne lata, do których należą m.in. poprawa gotowości i odporności na 
sytuacje kryzysowe w obszarze zdrowia publicznego. Zasadniczym celem powinno być wzmocnienie kondycji finansowej systemu zdrowotnego i stworzenie strategii i mechanizmów reagowania na nieprzewidziane wyzwania zdrowotne (np. pandemie).

\section{SŁoWA KLUCzowe:}

COVID-19, systemy ochrony zdrowia, finansowanie ochrony zdrowia

\section{Abstract}

\section{IMPACT OF COVID-19 ON THE FUNCTIONING OF HEALTH CARE IN THE CZECH REPUBLIC AND POLAND}

RESEARCH OBJECTIVE: The aim of the article is to present the changes in the functioning of health care systems in Poland and the Czech Republic caused by COVID-19 and to indicate the organizational and financial challenges and the consequences that they had to face.

THE RESEARCH PROBLEM AND METHODS: Research methods based on inductive reasoning related to literature studies, health reports, searches of Internet resources and available databases were used to achieve the aim of this study.

THE PROCESS OF ARGUMENTATION: Based on the information contained in the above-mentioned sources, secondary research was carried out, including an in-depth analysis of the most important actions taken in the surveyed countries in connection with the CoVID-19 pandemic, paying particular attention to their organizational and financial consequences. Information on the epidemiological and health situation became the background for consideration.

RESEARCH RESULTS: The primary outcome of the analysis is to show the changes occurring in health systems under the influence of COVID-19.

CONCLUSIONS, INNOVATIONS, AND RECOMMENDATIONS: The final conclusions and recommendations are related to the identification of challenges for health systems in the next years, which include improving preparedness and resilience to public health crises. Strengthening the financial health of the health system and developing strategies and mechanisms to respond to unforeseen health challenges (e.g. pandemics) should be a key objective.

\section{KeYwORDS:}

COVID-19, health systems, health financing 


\section{WSTĘP}

W roku 2019, podczas wystąpienia pierwszego ogniska przypadków choroby układu oddechowego w mieście Wuhan w prowincji Hubei w Chinach, Centrum Kontroli i Zapobiegania Chorobom przypisało tego typu stanom chorobowym nazwę COVID. Niosąca ze sobą wysoką śmiertelność choroba, wynikająca z zakażenia szybko rozprzestrzeniającego się wirusa SARS-CoV-2, została ostatecznie nazwana w 2020 r. przez WHO jako COVID-19 (Center for Disease Control and Prevention, 2019).

Pandemia COVID-19 wywarła ogromną presję na krajowe systemy opieki zdrowotnej zarówno w Europie, jak i pozostałych krajach świata, które w dużej mierze nie były przygotowane na jej skalę i tak wysoką śmiertelność wśród dynamicznie rosnącej liczby zakażonych. Kryzys poddał próbie systemy zdrowotne i ich odporność na zjawisko pandemii, w tym ich zdolność i możliwości do absorbowania, skutecznego reagowania i dostosowywania się do wstrząsów i zmian strukturalnych, przy jednoczesnym utrzymaniu codziennych działań.

Na całym świecie systemy opieki zdrowotnej nie zostały zaprojektowane i przygotowane do radzenia sobie z kryzysem o tak dużym wymiarze, nieprzewidywalnym, zakrojonym na szeroką skalę wyzwaniem zdrowotnym, które wymagało pilnej mobilizacji zasobów i dotyczyło całej populacji. Nie były na niego gotowe również Czechy i Polska, których działania w zakresie ochrony zdrowia są przedmiotem niniejszego opracowania. Celem artykułu jest przedstawienie zmian w funkcjonowaniu systemów ochrony zdrowia w tych krajach wywołanych pandemią COVID-19 oraz wskazanie na organizacyjne i finansowe wyzwania oraz skutki, którym musiały one sprostać.

Zmiany w systemach zdrowotnych, będące konsekwencją pandemii COVID19 a wynikające ze strategii i działań poszczególnych państw, opisali m.in.: Blumenthal, Fowler, Abrams, Collins (2020) Narain, Dawa, Bhatia (2020) oraz raport OECD (Beyond Containment, 2020). W przypadku Polski i Czech autorzy najczęściej poddają analizie wpływ Covid-19 na wybrany element systemu zdrowotnego. Badania dotyczyły personelu medycznego (Szmyd i in. 2021; Drobnik i in. 2021; Krok, Zarzycka 2020; Riad 2020) oraz usług zdrowotnych (Świerad 2020; David 2021). W literaturze przedmiotu dostrzegalny 
jest brak przekrojowego podejścia $\mathrm{w}$ analizie funkcjonowania systemów ochrony zdrowia w perspektywie organizacyjno-finansowych skutków pandemii.

\section{SYTUACJA EPIDEMIOLOGICZNA I ZDROWOTNA}

Pierwszy oficjalnie zgłoszony zgon z powodu COVID-19 w Europie miał miejsce 15 lutego 2020 r., przy czym wirus pojawił się w styczniu lub wcześniej (Spiteri, G. et al., 2020). Należy jednak zauważyć, że określenie liczby przypadków COVID-19 było uzależnione od strategii w zakresie testowania, intensywności testowania i różnic w faktycznym przenoszeniu wirusa. Tym samym, nie jest możliwe jednoznaczne potwierdzenie liczby osób zakażonych wirusem SARS-CoV-2, a dane obejmują jedynie przypadki potwierdzone. Jednocześnie należy zwrócić uwagę na fakt, że epidemia wiąże się ze zwiększoną liczbą zgonów spowodowanych nie tylko samym wirusem, ale i zakłóceniami w zakresie rutynowej opieki nad osobami przewlekle chorymi, jak i tymi, które mają w tym czasie trudności z otrzymaniem na czas niezbędnej opieki.

Tabela 1. Liczba zgonów w Czechach i Polsce w latach 2016-2020

\begin{tabular}{|l|c|c|c|c|c|c|}
\hline \multicolumn{1}{|c|}{ Państwo } & 2016 & 2017 & 2018 & 2019 & 2020 & COVID-19 \\
\hline Czechy & 107750 & 111443 & 112920 & 112362 & 131492 & 12070 \\
\hline Polska & 388009 & 402852 & 414200 & 409709 & 485604 & 29161 \\
\hline
\end{tabular}

Źródło: OECD data.

Dane zawarte w tabeli 1 wskazują na znaczący wzrost liczby zgonów we obu państwach. Porównując ze sobą rok 2020 i 2019 w Polsce zanotowano ok. 18,5\% więcej zgonów niż w roku poprzednim, w Czechach ok. 17\%. Porównując liczbę zgonów do przeciętnej z lat 2016-2019 wymienione kraje plasują się na takich samych pozycjach, natomiast liczba zmarłych była w 2020 roku odpowiednio wyższa o 20,3\% i 18,3\%. Według danych OECD na COVID-19 zmarło ok. 9,2\% mieszkańców Czech i ok. 6\% Polaków. W związku z tym, że większość osób zakażonych wirusem COVID-19 przeżywa, a szacowany wskaźnik śmiertelności zakażeń waha się w granicach 0,17-1,7\% (Meyerowitz-Katz, G., Merone, L. 2020), wydaje się, że w danych 
Wpływ COVID-19 na systemy ochrony zdrowia w Czechach i Polsce

uwzględniono również przypadki zgonów spowodowanych chorobami współistniejącymi.

Wykres 1. Nadmiarowe zgony w krajach UE (w \%)

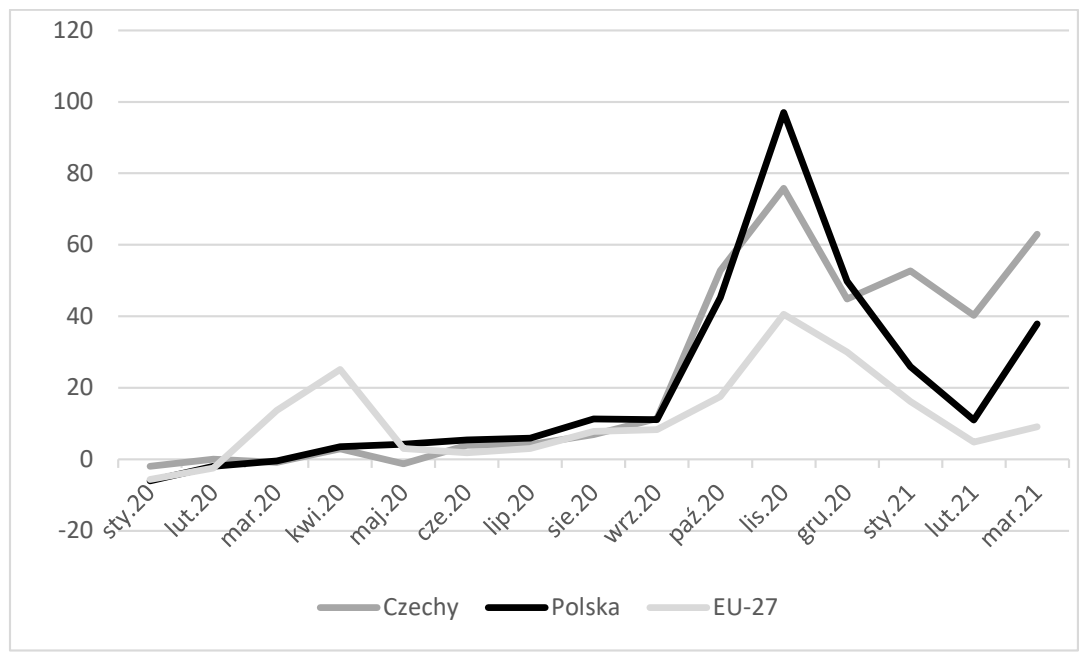

Źródło: EUROSTAT.

Dane przedstawione w tabeli 1 jak i na wykresie 1 świadczą o tym, że rok 2020 charakteryzował się zdecydowane większą niż w poprzednich latach liczbą zgonów we wszystkich krajach. Fakt ten należy wiązać ze zjawiskiem tzw. nadmiarowych zgonów, tj. zmianą liczby zgonów, które wystąpiły w każdym miesiącu w porównaniu do poziomu odniesienia, czyli średniej liczby zgonów w danym miesiącu w stosunku do przeciętnej z ostatnich czterech lat.

Kształty krzywych nadmiarowych zgonów dla UE-27 oraz Czech i Polski w analizowanych miesiącach nie pokrywają się. O ile do miesiąca września 2020 roku w badanych krajach nie zanotowano zwiększonej umieralności, o tyle można było ją zauważyć w pozostałych państwach UE, szczególnie w marcu i kwietniu tegoż roku, kiedy wskaźnik ten dla UE-27 przekroczył odpowiednio 13\% i 25\%. Z kolei pomiędzy majem i wrześniem 2020 roku sytuacja epidemiologiczna ustabilizowała się we wszystkich państwach Unii Europejskiej. Pierwsze symptomy negatywnych zmian zaobserwować można było we wrześniu 2020 roku, kiedy wskaźnik nadmiernych zgonów 
w Czechach i Polsce przekroczył 11\%, a dla UE-27 wyniósł 8,3\%. Od października 2020 do marca 2021 roku liczba nadmiarowych zgonów była najwyższa w całym analizowanym okresie, poprawiła się natomiast sytuacja w UE-27. Biorąc pod uwagę cały badany okres piętnastu miesięcy, w Czechach zanotowano średnio ok. 24\% nadmiernych zgonów, natomiast w Polsce ok. 20\%. Średnia dla UE-27 wyniosła w tym samym przedziale czasowym ok. $12 \%$.

Wraz z rozwojem nowej fali epidemii i jednocześnie nowego roku sytuacja epidemiczna zmieniła się. Aby można było w lepszy sposób zobrazować i porównać sytuację $\mathrm{w}$ badanych krajach, przedstawiono liczbę zgonów, jak również liczbę chorych oraz osób wyzdrowiałych, podając wartości względne, tj. przeliczone na $1 \mathrm{mln}$ mieszkańców.

Tabela 2. Liczba chorych, zmarłych, ozdrowieńców i liczba testów na COVID-19 (na 1 mln mieszkańców) dane na 5 czerwca 2021 r.

\begin{tabular}{|l|r|r|}
\hline & Czechy & Polska \\
\hline Liczba chorych & 155058 & 76037 \\
\hline Liczba zmarlych & 2811 & 1961 \\
\hline Liczba testów & 2381291 & 428881 \\
\hline Ozdrowieńcy & 151455 & 69939 \\
\hline
\end{tabular}

Źródło: https://www.worldometers.info/coronavirus/?utm_campaign=homeAdUOA?Si\#main_table (dostęp: 5.06.2021 r.).

Dane przedstawione w tabeli 2 jednoznacznie wskazują że większą niż w Polsce śmiertelność na $1 \mathrm{mln}$ mieszkańców zanotowano w Czechach, w których zmarłych było o 1135 osób więcej niż w Polsce. Jeżeli spojrzymy na liczbę zgonów przez pryzmat zachorowań, to sytuacja się zmienia. W Polsce zmarło ok. 2,6\% chorych na COVID-19, natomiast w Czechach ok. 1,8\%. Z liczbą zachorowań skorelowana jest liczba wykonanych testów, bowiem w Czechach wykonano ich 15,4 na jednego chorego, prawie trzykrotnie więcej niż w Polsce, tj. 5,64.

\section{STRATEGIA KRAJÓW W ZAKRESIE SZCZEPIEŃ NA COVID-19}

W Unii Europejskiej zdecydowano, że najbardziej skutecznym narzędziem walki z pandemią COVID-19 będzie opracowanie i wprowadzenie na rynek skutecznej i bezpiecznej szczepionki przeciwko 
wirusowi SARS-COV-2 (Komunikat Komisji do Parlamentu Europejskiego, 2020). Chodziło o to, by przedsięwzięcie udało się w przeciągu najbliższych 12-18 miesięcy (opracowanie szczepionki trwa zwykle ponad 10 lat). Ze względu na tak krótkie ramy czasowe, badania kliniczne były prowadzone równolegle $\mathrm{z}$ inwestycjami w zdolność produkcyjną i pozyskiwanie surowców, tak aby produkcję rozpocząć tuż po zakończeniu badań.

Ze względu na potrzebę szybkich rezultatów, wysokie koszty początkowe oraz duży odsetek nieudanych prób bezpiecznych i skutecznych szczepionek potrzebne było wsparcie finansowe dla przedsiębiorstw zajmujących się opracowaniem i produkcją szczepionki. Parlament Europejski i Rada Europejska udostępniły kwotę 2,7 mld EUR w ramach instrumentu wsparcia w sytuacjach nadzwyczajnych. Dodatkowo do końca maja 2020 roku pozyskano fundusze na kwotę 9,8 mld euro w ramach zainicjowanej przez Komisję Europejską kampanii. Komisja wniosła 1,4 mld EUR (w tym 1 mld z programu ramowego w zakresie badań naukowych i innowacji „Horyzont 2020”) $\mathrm{w}$ celu zapewnienia powszechnego i przystępnego cenowo dostępu do szczepień przeciwko koronawirusowi oraz leczenia i testów na obecność koronawirusa. Możliwe było również pozyskanie środków finansowych w formie pożyczek z Europejskiego Banku Inwestycyjnego.

Na szczeblu UE zdecydowano, że w celu uproszczenie negocjacji i obniżenia kosztów zakupu szczepionek Komisja Europejska odpowiedzialna jest za procedurę udzielania zamówień i zawarcie z poszczególnymi producentami umów zakupu szczepionek z wyprzedzeniem. Natomiast wprowadzenie do obrotu i zastosowanie szczepionek, w tym odpowiedzialność z tytułu wszelkich odszkodowań przewidzianych w danej umowie, będzie należała do państw członkowskich dokonujących zakupu.

Pod koniec grudnia 2020 roku firmy farmaceutyczne zakończyły pierwsze etapy badań klinicznych nad szczepionkami przeciwko COVID-19 i uzyskały warunkowe pozwolenie na ich dopuszczenie do obrotu ${ }^{1}$. 21 grudnia tegoż roku Komisja Europejska zgodziła się na dopuszczenie do sprzedaży szczepionki firmy BioNTech i Pfizer, 6 stycznia 2021 roku taką zgodę otrzymała Moderna,

1 https://ec.europa.eu/info/live-work-travel-eu/coronavirus-response/public -health/eu-vaccines-strategy_pl 
29 stycznia - AstraZeneca, a 11 marca 2021 roku firma Janssen Pharmaceutica NV (należąca do grupy Johnson \& Johnson). Do tej pory Komisja Europejska zabezpieczyła szczepionki przeciwko COVID-19 w ilości do 4,4 mld dawek².

Każdy z krajów przygotował własną strategię w zakresie szczepień, jednakże we wszystkich państwach są ona dobrowolne i bezpłatne.

W Republice Czeskiej wstępną strategię szczepień zatwierdzono 7 grudnia 2020 roku. Określono w niej trzy etapy budowy infrastruktury szczepień. Pod koniec grudnia rząd zaproponował zaktualizowaną wersję strategii szczepień, która została zatwierdzona 13 stycznia następnego roku. Za jej realizację odpowiedzialne są samorządy wojewódzkie, w tym organizację procesu szczepień w swoich regionach i utworzenie punktów szczepień. Na terenie całego kraju zaplanowano trzydzieści punktów dystrybucji szczepionek, a każdy z nich co najmniej jeden mobilny zespół szczepień. Wraz z uaktualnieniem strategii szczepień na nowo zdefiniowano grupy priorytetowe ${ }^{3}$. Pracownicy służby zdrowia, szpitali i domów seniora oraz osoby $\mathrm{w}$ wieku 80 lat i starsze znalazły się $\mathrm{w}$ grupie priorytetowej $1 \mathrm{~A}$ (około $7,5 \%$ całej populacji). Następna grupa priorytetowa $1 \mathrm{~B}$, ok. $37 \%$ ogółu populacji, obejmuje pozostałych pracowników służby zdrowia i opieki społecznej, nauczycieli, osoby powyżej 65. roku życia oraz inne grupy pacjentów wysokiego ryzyka, policjantów i strażaków oraz pracowników infrastruktury krytycznej państwa. Szczepienia rozpoczęto 27 grudnia 2020 roku.

W tym samym dniu również Polska rozpoczęła narodowy program szczepień ochronnych przeciwko COVID-19. Pracownicy służby zdrowia zostali potraktowani priorytetowo w zakresie szczepień (tzw. grupa „0"). Pacjenci z chorobą nowotworowa, którzy otrzymali chemioterapię lub radioterapię po 31 grudnia 2019 roku, zostali zaliczeni również do grupy priorytetowej ${ }^{4}$.

2 https://ec.europa.eu/info/live-work-travel-eu/coronavirus-response/ safe-covid-19-vaccines-europeans_pl

3 Ministry of Health Extraordinary Measure MZDR 1595/2021-1/MIN/KAN and the Vaccination Methodological Instructions from https://www.mzcr. cz/metodicky-pokyn-kampane-ockovani-planprovedeni/

4 https://www.infodent24.pl/lexdentpost/szczepionki-przeciwko-covid-19-kto-nalezy-do-grupy-zero, $117044 . \mathrm{html}$ 
Wpływ COVID-19 na systemy ochrony zdrowia w Czechach i Polsce

W styczniu 2021 roku rozpoczęła się rejestracja dla grupy 1, do której należą: mieszkańcy domów pomocy społecznej, zakładów opiekuńczo-leczniczych, zakładów pielęgnacyjno-opiekuńczych i innych miejsc stacjonarnego pobytu, a także osoby, które ukończyły 60. rok życia, począwszy od najstarszych oraz służby mundurowe, w tym Wojsko Polskie oraz nauczyciele.

Polityka informacyjna realizowana za pośrednictwem stron rządowych, mediów społecznościowych przyniosła efekty związane z liczbą osób, które skorzystały ze szczepień.

Tabela 3. Zaszczepieni (\% populacji)

\begin{tabular}{|l|c|c|c|}
\hline & Czechy & Polska & EU-27 \\
\hline Zaszczepieni częściowo & 22,46 & 16,81 & 20,02 \\
\hline W pełni zaszczepieni & 15,96 & 21,24 & 20,23 \\
\hline
\end{tabular}

Źródło: https://ourworldindata.org/covid-vaccinations (stan na 30 maja 2021 r.).

Dane przedstawione w tabeli 3 wskazuja, że do końca maja 2021 roku porównywalna część populacji Czech i Polski, tj. ok. 38\%, została zaszczepiona. Różnice wynikają jedynie z tego, że drugą dawkę szczepionki w Polsce przyjęło o ok. 5,5\% więcej obywateli niż w Czechach. Badane kraje w niewielkim zakresie odbiegają od innych państw UE-27, w których zaszczepiono ok. 2\% mniej osób.

\section{WYKORZYSTANIE ZASOBÓW LUDZKICH ORAZ DOSTĘP DO ŚRODKÓW MATERIAŁOWYCH I OCHRONY OSOBISTEJ}

Pandemia COVID-19 wywołała potrzebę wprowadzenia licznych zmian organizacyjnych w systemie zdrowotnym, a także większego zaangażowania potencjału ludzkiego, jak również zabezpieczenia niezbędnego sprzętu ochrony osobistej i poszerzenia możliwości rozbudowy potencjału szpitali w zakresie zwiększenia liczby łóżek dla pacjentów zakażonych wirusem SARS-CoV-2. 
Tabela 4. Wykorzystywanie zasobów ludzkich związanych z przeciwdziałaniem pandemii COVID-19

\begin{tabular}{|l|c|c|}
\hline \multirow{2}{*}{ Rodzaj działań } & \multicolumn{2}{c|}{ Państwo } \\
\cline { 2 - 3 } & Czechy & Polska \\
\hline Zaangażowanie studentów kierunków medycznych & $*$ & $*$ \\
\hline $\begin{array}{l}\text { Wsparcie wojska w działalności niektórych placówek ochrony } \\
\text { zdrowia }\end{array}$ & $*$ & $*$ \\
\hline Wsparcie psychologiczne dla pracowników ochrony zdrowia & $*$ & $*$ \\
\hline Wstrzymanie procedur planowych & $*$ & $*$ \\
\hline Telemedycyna w POZ & $*$ & $*$ \\
\hline
\end{tabular}

Źródło: opracowanie własne na podstawie European Observatory of Health Systems and Policies, https://www.covid19healthsystem.org/mainpage.aspx

W Czechach w dniu 15 marca 2020 roku rząd zabronił wszystkim pracownikom medycznym korzystania z urlopów w czasie stanu wyjątkowego, uchwała ta została odwołana 10 kwietnia tego samego roku (Czech Republic Government Resolutions no. 216). Natomiast 17 marca 2020 roku (Ministry of Health Extraordinary Measures issued on March 16, 2020) Ministerstwo Zdrowia nakazało szpitalom wstrzymanie planowych i nieostrych procedur (Ministry of Health recommendation for healthcare providers, issued on April 14, 2020 ).

W związku z rosnącymi wskaźnikami zakażeń studenci IV i $\mathrm{V}$ roku medycyny zostali powołani uchwałą rządu do pełnienia dyżurów w październiku 2020 roku. Obowiązek pracy studentów medycyny został odwołany 10 grudnia 2020 roku, natomiast 8 marca następnego roku obowiązek pracy w podmiotach medycznych dla studentów kierunków medycznych przywrócono. Republika Czeska była jedynym krajem w Europie, który zastosował instrument obowiązku pracy studentów ${ }^{5}$.

Z kolei żołnierze byli angażowani jako opiekunowie i personel pomocniczy w dużych szpitalach i placówkach opieki społecznej, gdzie wystąpiły znaczące niedobory kadrowe. 9 listopada 2020 roku rząd skierował do służby dodatkowych 540 żołnierzy, a ich łączna liczba wzrosła do 900 (z czego 400 wysłano do pomocy w szpitalach). W styczniu $2021 \mathrm{r}$. braki kadrowe w szpitalach stały się krytyczne. 22 stycznia tegoż roku 728 żołnierzy pomagało w 125 szpitalach i placówkach opieki społecznej.

5 https://www.zdravotnickydenik.cz/blog/k-pracovni-povinnosti-studentu/ 
3 marca 2021 roku rząd nałożył obowiązek pracy na specjalistów i innych pracowników służby zdrowia zatrudnionych w placówkach prywatnych, z wyjątkiem lekarzy pierwszego kontaktu. Wojewodowie mogli ich wezwać do pracy na wniosek szpitali w regionie, w którym mieszkają.

W Polsce kompleksowe przepisy dotyczące zapobiegania i zwalczania COVID-19, które zostały przyjęte w parlamencie 29 marca 2020 roku, obejmują kilka środków dotyczących pracowników służby zdrowia (Dz.U. z 2020 r. poz. 567, 695, 1493, 1747). Aby zapobiec niedoborowi personelu medycznego, lekarze, którzy nie posiadają specjalizacji w zakresie w chorób zakaźnych lub nie są anestezjologami, jak również lekarze w trakcie szkolenia specjalistycznego, mogą zostać oddelegowani (na okres do trzech miesięcy) na oddziały chorób zakaźnych lub do innych placówek, w których potrzebna jest pomoc.

Nadal działają przychodnie podstawowej opieki zdrowotnej (tzw. POZ), choć większość usług jest świadczona zdalnie (tzw. teleporady). Studenci ostatniego roku medycyny, farmacji, analityki medycznej, pielęgniarstwa i ratownictwa medycznego mogą pełnić role pomocnicze. Podejmowane są również próby zwiększenia liczby pielęgniarek poprzez wprowadzenie uproszczonej procedury umożliwiającej powrót do pracy pielęgniarkom i położnym bez praktyki zawodowej (które miały co najmniej pięcioletnią przerwę).

Minister Obrony Narodowej może przekazać do dyspozycji Głównego Inspektora Sanitarnego lub wojewody, żołnierzy (Dz.U. z 2020 r. poz. 1845, 2112, 2401, z 2021 r. poz. 159, 180, 255, 611). W walkę z pandemią zaangażowali się żołnierze Wojsk Obrony Terytorialnej, którzy są odpowiedzialni za wstępną selekcję pacjentów oraz pobieranie wymazów w punktach pobrań ${ }^{6}$.

W zakresie wsparcia psychologicznego dla personelu medycznego Naczelna Izba Lekarska podjęła inicjatywę stworzenia bazy danych specjalistów z zakresu zdrowia psychicznego nieodpłatnie, przez Internet lub telefonicznie.

6 https://media.terytorialsi.wp.mil.pl/informacje/587337/wspieraja-szpitale -pobieraja-wymazy-dostarczaja-srodki-ochrony-osobistej 


\section{ZMIANY W INFRASTRUKTURZE MEDYCZNEJ WYWOŁANE PANDEMIĄ COVID-19}

Proces leczenia i prowadzenia działań prewencyjnych wymaga zapewnienia odpowiedniej infrastruktury, tj. szpitali, sprzętu, środków ochrony osobistej oraz kadry medycznej.

Tabela 5. Działania państw związane z zapewnieniem infrastruktury szpitalnej, środków ochrony osobistej i sprzętu szpitalnego (medycznego)

\begin{tabular}{|l|c|c|}
\hline \multirow{2}{*}{ Rodzaj działań } & \multicolumn{2}{c|}{ Państwo } \\
\cline { 2 - 3 } & Czechy & Polska \\
\hline $\begin{array}{l}\text { Produkcja środków dezynfekcyjnych, rękawiczek i maseczek } \\
\text { ochronnych we własnym kraju }\end{array}$ & $*$ & $*$ \\
\hline Zakup środków ochronnych w krajach trzecich, np. Chinach & $*$ & $*$ \\
\hline Zakup dodatkowego sprzętu medycznego (np. respiratorów) & $*$ & $*$ \\
\hline $\begin{array}{l}\text { Udział władz centralnych w dostarczaniu środków i sprzętu } \\
\text { medycznego }\end{array}$ & $*$ & $*$ \\
\hline Szpitale tymczasowe & $*$ & $*$ \\
\hline
\end{tabular}

Źródło: opracowanie własne na podstawie European Observatory of Health Systems and Policies, https://www.covid19healthsystem.org/mainpage.aspx

W Czechach wstępnie oszacowano, że 136 ośrodków intensywnej terapii dysponowało 2080 respiratorami płucnymi i 4481 łóżkami na OIOM, przy czym 37\% łóżek na oddziałach intensywnej terapii i 61\% respiratorów płucnych było nieobsadzonych do 22 marca 2020 $\mathrm{roku}^{7}$. Pod koniec kwietnia 2020 roku zgłoszona liczba łóżek na oddziałach intensywnej terapii wynosiła 4148 (38,9 na 100000 osób) oraz 1968 respiratorów płucnych (18,5 na 100000 osób), przy czym wolna pojemność wynosiła odpowiednio $41 \%$ i $66 \%{ }^{8}$. Łącznie było 75 łóżek wyposażonych w ECMO (aparat do pozaustrojowego natleniania krwi), a wskaźnik wolnej pojemności wynosił $86 \%$. Na dzień 11 listopada Czesi posiadali 2115 respiratorów, w tym 300

7 https://koronavirus.mzcr.cz/wp-content/uploads/2020/03/Dostupnost-intenzivn \%C3\%ADp\%C3\%A9\%C4\%8De-pro-hospitalizovan\%C3\%A9-pacienty-s-COVID-19.pdf

8 https://koronavirus.mzcr.cz/wp-content/uploads/2020/04/Aktu\%C3\%A11n\%C3\%AD-stavsyst \%C3\%A9mu-intenzivn\%C3\%AD-p\%C3\%A9\%C4\%8De. pdf 
dodatkowych, zakupionych przez rząd czeski lub otrzymanych w ramach solidarności międzynarodowej.

Środki ochrony indywidualnej (PPE) zostały zakupione centralnie przez Ministerstwo Zdrowia i Ministerstwo Spraw Wewnętrznych na podstawie uchwały rządu. 20 marca 2020 roku ustanowiono transport lotniczy między Republiką Czeską a Chinami ${ }^{9}$. Rząd podpisał umowy kupna z niektórymi producentami krajowymi, w tym z Czeskim Uniwersytetem Technicznym i nowo powstałym przedsiębiorstwem TRIX Connection na produkcję nowego typu respiratora FFP3.

Do połowy lutego 2021 roku MZ stosowało strategię polegającą na przewożeniu pacjentów z wirusem COVID-19 z przeciążonych szpitali do szpitali o większej liczbie łóżek, w tym z wykorzystaniem służb ratowniczych. Jednak 18 lutego br. ten system redystrybucji pacjentów załamał się z powodu pełnego obłożenia wszystkich szpitali w Czechach $^{10}$.

W październiku 2020 roku wybudowano tymczasowy szpital w Pradze z liczbą 500 łóżek dla pacjentów covidowych. Został on jednak rozwiązany w lutym $2021 \mathrm{r}$. z powodu braku wykwalifikowanego personelu i wysokich kosztów operacyjnych. Kolejna tymczasowa placówka szpitalna została otworzona pod koniec października 2020 roku w Brnie w budynkach wystawowych (z liczbą 300 łóżek), jednakże w styczniu następnego została przekształcona w punkt szczepień.

W Polsce we wrześniu 2020 roku powstały nowe rozwiązania dotyczące podziału referencyjnego szpitali covidowych, które podzielono na trzy poziomy. We wszystkich szpitalach należących do sieci utworzono miejsca dla pacjentów z podejrzeniem koronawirusa. W 87 oddziałach zakaźnych i obserwacyjno-zakaźnych szpitali zakaźnych zabezpieczono miejsca do leczenia osób zarażonych koronawirusem. W sumie zabezpieczono ok. 4 tys. miejsc dla pacjentów wymagających opieki typowo internistycznej. Pacjenci z rozpoznanym już koronawirusem, wymagający wysokospecjalistycznego leczenia, są kierowani również do szpitali wielospecjalistycznych udzielających

9 https://zdopravy.cz/letecky-most-z-ciny-pokracuje-behem-prodlouzeneho-vikendu-prileti-seststroju-46637/

10 https:/www.idnes.cz/zpravy/domaci/nemocnice-prevoz-pacientu-covid-kornavirus.A210218_141533_domaci_remy 
świadczeń osobom niezakażonym SARS-COV-2. W tych szpitalach przygotowano ponad dwa tysiące miejsc ${ }^{11}$.

19 października 2020 roku Ministerstwo Zdrowia ogłosiło, że w celu zwiększenia liczby łóżek szpitalnych dla pacjentów z COVID-19, część szpitali powiatowych wyznaczono jako szpitale covidowe (10 tys. sztuk łóżek). Ministerstwo Zdrowia zapowiedziało, że część szpitali wojewódzkich zostanie wyznaczona jako szpitale COVID-19. W wyniku tej operacji przybyło ok. trzy tysiące łóżek. Minister zdrowia podał, że w całym kraju funkcjonuje piętnaście tysięcy łóżek dla pacjentów z COVID-19, a ok. $60 \%$ z nich zostało już zajętych ${ }^{12}$.

Zarówno rząd, jak i niektóre samorządy zapewniły finansowanie sprzętu medycznego i diagnostycznego oraz sprzętu ochrony osobistej lub udostępniły obiekty w celu przyjęcia nadwyżki pacjentów nieobjętych programem COVID-19 z wyznaczonych szpitali zakaźnych.

Ze środków MZ wydano na ten cel do końca 2020 roku sumę ok. $833 \mathrm{mln} \mathrm{zt}^{13}$.

W październiku władze centralne podjęły również decyzję o rozpoczęciu budowy szpitali tymczasowych. W Warszawie przekształcono Stadion Narodowy w szpital z 500 tóżkami covidowymi. Również $\mathrm{w}$ innych miastach wykorzystano hale sportowe i targowe, szpitale i sanatoria. Łączna liczba łóżek wyniosła 5500 sztuk $^{14}$. Większość tymczasowych szpitali została obecnie przekształcona w punkty szczepień. W całym kraju istnieją 7240 punkty szczepień ${ }^{15}$.

11 https://www.gov.pl/web/koronawirus/plany-na-jesien--strategia-walki -z-pandemia-koronawirusa

12 https://www.gov.pl/web/zdrowie/podwojenie-bazy-lozkowej-i-udogodnienia-dla-personelu-medycznego

13 https://www.gov.pl/web/zdrowie/covid---ewidencja-zakupow

14 https://www.politykazdrowotna.com/66189,lista-szpitali-tymczasowych-w-polsce

15 https://www.gov.pl/web/szczepimysie/mapa-punktow-szczepien\# 


\section{ZAKRES FINANSOWANIA ŚWIADCZEŃ ZWIAZZANYCH Z PRZECIWDZIAŁANIEM ROZPRZESTRZENIANIA SIĘ PANDEMII COVID-19}

Wszystkie te działania, polegające na poszerzeniu potencjału materialnego i ludzkiego podjęte przez władze centralne, lokalne i kasy chorych czy fundusze zdrowia, nie byłyby możliwe bez dodatkowego finansowania. Systemy opieki zdrowotnej Polski i Czech oparte są na ustawowym ubezpieczeniu zdrowotnym i pokrywały niezbędne koszty związane z COVID-19.

Tabela 6. Finansowanie świadczeń związanych z przeciwdziałaniem pandemii COVID-19

\begin{tabular}{|l|c|c|}
\hline \multicolumn{1}{|c|}{ Rodzaj działań } & \multicolumn{2}{c|}{ Państwo } \\
\cline { 2 - 3 } & Czechy & Polska \\
\hline $\begin{array}{l}\text { Dodatkowe finansowanie świadczeń związanych z pandemią } \\
\text { COVID-19 }\end{array}$ & $*$ & $*$ \\
\hline $\begin{array}{l}\text { Środki na walkę z pandemią COVID-19 pochodzą ze środków } \\
\text { publicznego płatnika lub płatników }\end{array}$ & $*$ & $*$ \\
\hline $\begin{array}{l}\text { Środki na walkę z pandemią COVID-19 pochodzą z budżetu } \\
\text { państwa lub samorządu lokalnego }\end{array}$ & $*$ & $*$ \\
\hline Dodatkowe wynagrodzenia dla pracowników ochrony zdrowia & $*$ & $*$ \\
\hline
\end{tabular}

Źródło: opracowanie własne na podstawie European Observatory of Health Systems and Policies, https://www.covid19healthsystem.org/mainpage.aspx

W Czechach pod koniec kwietnia 2020 roku Parlament zatwierdził rządową propozycję zwiększenia tzw. płatności państwowej, czyli dotacji z budżetu państwa na ubezpieczenie zdrowotne, odprowadzanej w imieniu osób nieaktywnych zawodowo (dzieci, studenci, bezrobotni, seniorzy itp.). Począwszy od 1 czerwca tego samego roku płatność ta została zwiększona o $500 \mathrm{CZK}$ na osobę miesięcznie (z 1067 CZK do 1567 CZK), a dalszy wzrost o 200 zaplanowano na 1 stycznia następnego roku (do $1767 \mathrm{CZK}$ ). Fundusze te oznaczają dodatkowe 21 miliardów CZK (778 milionów EUR) w tym roku i dodatkowe 50 miliardów CZK (1,85 miliarda EUR) w 2021 r. (Ministry of Healthcare website, accessed April 11, 2020). W czerwcu 2020 roku czeski parlament uchwalił zmianę legislacyjna, tzw. Dyrektywa o refundacji rekompensat (CRD), która rekompensuje świadczeniodawcom straty finansowe wynikające $z$ obniżonych świadczeń opieki zdrowotnej w związku z pandemią COVID-19. Od 1 lipca 
tegoż roku, w związku z mniejszą liczbą wykonanych planowych świadczeń w szpitalach, przyjęto nowy minimalny poziom finansowania przez kasy chorych działalności szpitali wynoszący $79-82 \%$ zrealizowanych w 2018 roku świadczen ${ }^{16}$. Zwiększono refundację FFS (fee-for-service) dla sektora ambulatoryjnego, refundację za dzień łóżka dla świadczeniodawców opieki długoterminowej oraz zindeksowano refundację z budżetu perspektywicznego dla szpitali, aby uwzględnić ich rosnące koszty wynikające z zakupu środków ochrony indywidualnej ${ }^{17}$. Rezerwa budżetowa została zwiększona o 59,3 mld CZK (2,19 mld EUR), co miało na celu zapobieganie rozprzestrzenianiu się epidemii ${ }^{18}$. W marcu 2021 roku rząd zatwierdził specjalną premię dla pracowników stacjonarnej opieki zdrowotnej za okres od 1 października 2020 do 28 lutego 2021 roku (75 000 CZK) wynoszącą 91\% średniego miesięcznego wynagrodzenia w 2019 roku dla lekarzy i $170 \%$ średniego miesięcznego wynagrodzenia w tym samym roku dla pielęgniarek (dane z Ministerstwa Zdrowia i UZIS). W przypadku pracowników niemedycznych premia wynosiła 30000 CZK na jednego pełnoetatowego pracownika (Government Resolution No. 296, issued on March 23, 2020).

W Polsce w ramach działań antykryzysowych utworzono Fundusz Przeciwdziałania COVID-19. Środki Funduszu na ochronę zdrowia, którymi dysponuje Ministerstwo Zdrowia, w 2020 wyniosły ok. $8 \mathrm{mln}$ $\mathrm{z}^{19}$, natomiast w roku 2021 planowane są na poziomie ok. $17,7 \mathrm{mld}$ zł, w tym ok. 3,2 mld zł na zapobieganie, przeciwdziałanie i zwalczanie COVID-1920.

W celu zapłaty za świadczenia związane z COVID-19, NFZ ustalił katalog usług podlegający finansowaniu oraz ich ceny (Zarządzenie

16 https://www.mzcr.cz/tiskove-centrum-mz/ministerstvo-zdravotnictvi-odeslalo-kompenzacnivyhlasku-do-sbirky-zakonu/

17 https://www.mzcr.cz/tiskove-centrum-mz/ministerstvo-zdravotnictvi-odeslalo-kompenzacni-vyhlasku-do-sbirky-zakonu/

18 https://www.mfcr.cz/cs/aktualne/tiskove-zpravy/2020/vlada-schvalila -novelu-zakona-o-statnim-37959

19 https://www.gazetaprawna.pl/wiadomosci/artykuly/1497377,senat-gadomski-wydatki-w-tym-roku-na-walke-z-covid-19-wyniosa-okolo-8-mld-zl.html

20 https://businessinsider.com.pl/firmy/dla-firm/fundusz-przeciwdzialania -covid-19-przedluzony-przez-premiera-morawieckiego/qt3npch 
Wpływ COVID-19 na systemy ochrony zdrowia w Czechach i Polsce

Nr 32/2020/DSOZ 08-03-2020; Zarządzenie Nr 19/2021/DSOZ 27-012021). Od lipca 2020 roku NFZ płaci wszystkim zakontraktowanym świadczeniodawcom dodatkowe 3\% na pokrycie kosztów podwyższonego reżimu sanitarnego. Środki te pochodzą z budżetu państwa ${ }^{21}$. Samorządy wojewódzkie, które są właścicielami zakładów opieki zdrowotnej, wspierają swoje placówki poprzez przekazywanie środków finansowych, głównie na zakup sprzętu medycznego lub środków ochrony indywidualnej.

Po zniesieniu we wrześniu ograniczenia dotyczącego pracy w więcej niż jednym miejscu, świadczenie pieniężne w wysokości 50\% wynagrodzenia (nie więcej niż 10000 zł), otrzymali wszyscy pracownicy medyczni zaangażowani w opiekę nad pacjentami COVID-19 Decyzją Ministra Zdrowia świadczenie to od 1 listopada 2020 roku podwyższono do $100 \%$ wynagrodzenia (limit 15000 zł). Jednocześnie rozszerzono grupę beneficjentów o pracowników służby zdrowia wykonujących transport i pracujących w laboratoriach. Na ten cel przeznaczono łącznie 3,2 miliarda złotych. Według informacji NFZ wynagrodzenie to otrzymało 99714 pracowników medycznych z 550 placówek w całej Polsce (Zarządzenie Nr 19/2021/DSOZ 27-01-2021).

\section{WNIOSKI I REKOMENDACJE}

Negatywne skutki gospodarcze, społeczne i demograficzne oraz straty, jakie poniosły poszczególne kraje z powodu pandemii COVID-19, miały charakter globalny. Dane epidemiologiczne i zdrowotne wskazują na wyjątkową zaraźliwość wirusa SARS-COV-2 i wysoką śmiertelność spowodowaną chorobą COVID-19. W Czechach i Polsce odnotowano znaczący wzrost liczby zgonów. Według danych OECD w 2020 roku zmarło odpowiednio 131,5 tys. i 485,6 tys. osób, tj. przeciętnie o ok. 17,8\% więcej osób niż w 2019 roku, a wirus wpłynął na umieralność w ok. 7,6\%.

Systemy opieki zdrowotnej mają zasadnicze znaczenie dla utrzymania stabilności krajów zarówno w wymiarze gospodarczym, społecznym, jak i demograficznym. Tę szczególną rolę systemów

21 https://pulsmedycyny.pl/nfz-bedzie-dodatkowe-finansowanie-placowek-medycznych-996240 
ochrony zdrowia uwypukliła pandemia, jednocześnie obnażając ich słabości. Walka ze skutkami zakażenia SARS-COV-2 koncentruje się przede wszystkim na przeciwdziałaniu rozprzestrzeniania się choroby i zapewnieniu opieki nad zakażonymi pacjentami. Przez cały czas trwania pandemii, przy dynamicznym wzroście zakażeń i wysokiej śmiertelności, Polska i Czechy podjęły działania związane z wprowadzanie nowych, innowacyjnych modeli świadczenia usług zdrowotnych, w tym wirtualnych platform opieki nad pacjentami czy też rozwinięcia narzędzi telemedycyny. Zapewnienie infrastruktury medycznej, tj. poszerzenia/zwiększeniem bazy szpitalnej, zapewnienia kadry medycznej przy jej znaczących niedoborach czy zabezpieczenie podstawowych środków ochrony osobistej, stało się ogromnym wyzwaniem, którym wspomniane państwa bez wzajemnego wsparcia i wsparcia Unii Europejskiej zapewne by nie podołały. Doświadczenia związane z pandemią uwidoczniły problemy dotykające systemy ochrony zdrowia, ich organizację i finansowanie. Wśród nich na szczególną uwagę zasługuje kwestia poprawy gotowości i odporności na sytuacje kryzysowe w obszarze zdrowia publicznego, ale także skuteczności podstawowych działań. Zasadniczym celem powinno być wzmocnienie kondycji finansowej systemu zdrowotnego, stworzenie zdolności szybkiego reagowania w łańcuchu dostaw medycznych, inwestowanie w nowe programy wsparcia i rozwoju pracowników oraz modele zatrudnienia, poprawę elastyczności i możliwości rozbudowy w zakresie opieki stacjonarnej.

Wydatki na ochronę zdrowia poniesione przez Polskę i Czechy w 2020 roku były zdecydowanie wyższe w stosunku do roku $2019 \mathrm{i}$ lat poprzednich. Z uwagi na fragmentaryczność danych, udostępnianych przez różne podmioty związane z funkcjonowaniem systemów zdrowotnych, oszacowanie wydatków i poniesionych kosztów jest niezwykle skomplikowane. Można bowiem odnaleźć jedynie informacje dotyczące dodatkowych nakładów ponoszonych przez Ministerstwa Zdrowia, kasy chorych, fundusze zdrowia czy też specjalnie powołane przez poszczególne państwa podmioty do walki ze skutkami COVID-19 (jak np. w Polsce Fundusz Przeciwdziałania COVID-19 FPcov-19). Rozproszenie danych, tak istotnych z punktu widzenia zarządzania systemem, i ujmowanie ich, a czasem powielanie w różnych statystykach, zaciemnia faktyczny obraz kosztów pandemii. W Polsce koszty NFZ zwiększyły się w stosunku do planu na 2020 
rok o ok. 10 mld zł i były wyższe od tych z 2019 roku o ok. 11,4 mld zł. W budżecie państwa zwiększono wydatki w stosunku do planowanych o ok. 2 mld zł, a z FP cov-19 przeznaczono na ochronę zdrowia ok. 8 mld zł. Niemniej nie do końca wiadomo, jaka część środków z budżetu Ministerstwa Zdrowia została przekazana do NFZ i czy podobna sytuacja nie miała miejsca w przypadku FP cov-19.

Kryzys zdrowotny niezwykle wyraźnie ujawnił znaczenie kluczowych segmentów sektora publicznego, w tym w szczególności ochrony zdrowia, dla funkcjonowania całej gospodarki. Organy regulacyjne powinny wykorzystać te doświadczenia i na podstawie analizy przebiegu pandemii i podejmowanych decyzji opracować kompleksową strategię obejmującą zdecydowane działania zarówno na szczeblu samorządowym, krajowym, jak i unijnym. Potrzebne jest stworzenie planów kryzysowych, scenariuszy, stres testów określających szczegółowe rozwiązania jak również podejmowanie szybkich działań prewencyjnych w momencie pojawiania się wirusa (nawet tych najprostszych w postaci maseczek ochronnych). Jednocześnie nadal konieczne jest prowadzenie działań prewencyjnych, szczególnie upowszechnianie szczepień (wobec $40 \%$ zaszczepionej populacji krajów UE wg danych z maja 2021 r., co niestety nie gwarantuje nabycia tzw. odporności populacyjnej).

Niezbędne jest również prowadzenie dalszych badań naukowych związanych z pogłębionymi analizami dotyczącymi zmian zachodzących w systemach ochrony zdrowia wywołanych przez epidemię COVID-19, w tym analiza pełnych danych statystycznych pozwalających na uchwycenie tendencji i skutków w wymiarze krajowym i globalnym.

\section{Bibliografia}

Blumenthal, D., Fowler, E.J., Abrams, M., Collins S.R., (2020). Covid-19 Implications for the Health Care System. New England Journal of Medicine, 383, 1483-1488. DOI: 10.1056/NEJMsb2021088

David, J., Sibikova, M., Amaratunga, S.A., Lebl, J. (2021). COVID-19 Pandemic in the Czech Republic: Substantial Decline of the Demand for Pediatric Healthcare Services. Klinische Pädiatrie, 233(01), 40-42.

Drobnik, J., Susło, R., Pobrotyn, P., Fabich, E., Magiera, V., Diakowska, D., Uchmanowicz, I. (2021). COVID-19 among healthcare workers in the 
University Clinical Hospital in Wroclaw, Poland. International Journal of Environmental Research and Public Health, 18(11), 5600. https://doi. org/10.3390/ijerph18115600

Krok, D., Zarzycka, B. (2020). Risk perception of COVID-19, meaning-based resources and psychological well-being amongst Healthcare Personnel: The mediating role of copin. Journal of clinical medicine, 9(10), 3225. https://doi.org/10.3390/jcm9103225

Meyerowitz-Katz, G. and L. Merone (2020. A systematic review and meta-analysis of published research data on COVID-19 infection-fatality rate. International Journal of Infectious Diseases, 101, 138-148. http:// dx.doi.org/10.1016/j.ijid.2020.09.1464

Narain, J.P., Dawa, N., \& Bhatia, R. (2020). Health system response to COVID-19 and future pandemic, Journal of Health Management, 22(2), 138-145. https://doi.org/10.1177\%2F0972063420935538

Riad, A., Pokorná, A., Attia, S., Klugarová, J., Koščík, M., Klugar, M. (2021). Prevalence of COVID-19 Vaccine Side Effects among Healthcare Workers in the Czech Republic. Journal of Clinical Medicine, 10(7), 1428. https://doi.org/10.3390/jcm10071428

Spiteri, G. et al. (2020, 5 marca). First cases of coronavirus disease 2019 (COVID-19) in the WHO European Region, 24 January to 21 February 2020, Euro Surveill. 25(9), 2000178. doi: 10.2807/1560-7917. ES.2020.25.9.2000178.

Szmyd, B., Karuga, F.F., Bartoszek, A., Staniecka, K., Siwecka, N., Bartoszek, A., Błaszczyk M., Radek, M. (2021). Attitude and behaviors towards SARS-CoV-2 vaccination among healthcare workers: A cross-sectional study from Poland. Vaccines, 9(3), 218. https://doi. org/10.3390/vaccines 9030218

Świerad, M., Dyrbuś, K., Szkodziński, J., Zembala, M.O., Kalarus, Z., Gąsior, M. (2020). Telehealth visits in a tertiary cardiovascular centre as a response of the healthcare system to the pandemic of SARS-CoV-2 in Poland. Internal Medicine, 130 (7-8). DOI: 10.20452/pamw.15370

\section{Akty prawne}

Ustawa z dnia 31 marca 2020 r. o zmianie niektórych ustaw w zakresie systemu ochrony zdrowia związanych z zapobieganiem, przeciwdziałaniem i zwalczaniem COVID-19 Dz.U. 2020 poz. 567 (2020) (Polska). https://www.dziennikustaw.gov.pl/D2020000056701.pdf

Ustawa $\mathrm{z}$ dnia 5 grudnia 2008 r. o zapobieganiu oraz zwalczaniu zakażeń i chorób zakaźnych u ludzi Dz.U. 2020 poz. 1845 (2021) (Polska). https://isap.sejm.gov.pl/isap.nsf/download.xsp/WDU20082341570/U/ D20081570Lj.pdf 
Wpływ COVID-19 na systemy ochrony zdrowia w Czechach i Polsce

Czech Republic Government Resolutions no. 216 (issued March 15), no. 278 (issued March 23), and no. 403 (issued April 9). https://www. mpo.cz/en/guidepost/for-the-media/press-releases/overview-of-government- resolutions-since-the-declaration-of-the-state-of-emergency--253720/

Ministry of Health Extraordinary Measures issued on March 16, 2020 (MZDR 12066/2020-1/MIN/KAN) and March 19, 2020 (MZDR 12312/2020-2/MIN/KAN). https://www.randls.com/en/coronavirus/ list-of-coronavirus-regulations/extraordinary-measures-of-the-ministry-of-health/Ministry of Health recommendation for healthcare providers, issued on April 14, 2020.

Ministry of Health Extraordinary Measure MZDR 1595/2021-1/MIN/ KAN and the Vaccination Methodological Instructions from https:// www.mzcr.cz/metodicky-pokyn-kampane-ockovani-planprovedeni/

Komunikat Komisji do Parlamentu Europejskiego, Rady Europejskiej, Rady i Europejskiego Banku Inwestycyjnego. Strategia UE dotycząca szczepionek przeciwko Covid-19, Bruksela, dnia 17.6.2020 r. $\operatorname{COM}(2020)$ 245. https://eur-lex.europa.eu/legal-content/PL/ TXT/?uri=CELEX:52020DC0245

Zarządzenie Nr 32/2020/DSOZ 08-03-2020 w sprawie zasad sprawozdawania oraz warunków rozliczania świadczeń opieki zdrowotnej związanych z zapobieganiem, przeciwdziałaniem i zwalczaniem COVID-19 (tekst ujednolicony z dnia 01.07.2020). https://www.nfz. gov.pl/zarzadzenia-prezesa/zarzadzenia-prezesa-nfz/zarzadzenie-nr-322020dsoz,7144.html

Zarządzenie Nr 19/2021/DSOZ 27-01-2021 zmieniające zarządzenie w sprawie zasad sprawozdawania oraz warunków rozliczania świadczeń opieki zdrowotnej związanych z zapobieganiem, przeciwdziałaniem i zwalczaniem COVID-19. https://www.nfz.gov.pl/zarzadzenia-prezesa/zarzadzenia-prezesa-nfz/zarzadzenie-nr-192021dsoz,7306. html

Internet

Center for Disease Control and Prevention. (2019). Novel Coronavirus. Wuhan, China. CDC. Retrieved from https://www.cdc.gov/coronavirus/2019-ncov/prevent-getting-sick/how-covid-spreads.html?CDC_ AA_refVal=https $\% 3 \mathrm{~A} \% 2 \mathrm{~F} \% 2 \mathrm{Fwww} . c d c . g o v \% 2 \mathrm{~F}$ coronavirus $\% 2 \mathrm{~F}-$ 2019-ncov\%2Fabout\%2Findex.html. (dostęp: 5.06.2021)

https://ec.europa.eu/info/live-work-travel-eu/coronavirus-response/ public-health/eu-vaccines-strategy_pl (dostęp: 5.06.2021) 
https://ec.europa.eu/info/live-work-travel-eu/coronavirus-response/safe-covid-19-vaccines-europeans_pl (dostęp: 3.06.2021)

https://www.infodent24.pl/lexdentpost/szczepionki-przeciwko-covid-19-kto-nalezy-do-grupy-zero,117044.html (dostęp: 3.06.2021)

https://koronavirus.mzcr.cz/doporuceni-poskytovatelum-zdravotni-pece/ (dostęp: 4.06.2021)

https://www.zdravotnickydenik.cz/blog/k-pracovni-povinnosti-studentu/ (dostęp: 5.06.2021)

https://media.terytorialsi.wp.mil.pl/informacje/587337/wspieraja-szpitale-pobieraja-wymazy-dostarczaja-srodki-ochrony-osobistej (dostęp: 2.06.2021)

https://koronavirus.mzcr.cz/wp-content/uploads/2020/03/Dostupnost-intenzivn \%C3\%ADp\%C3\%A9\%C4\%8De-pro-hospitalizovan\%C3\%A9-pacienty-s-COVID-19.pdf (dostęp: 2.06.2021)

https://koronavirus.mzcr.cz/wp-content/uploads/2020/04/Aktu\%C3\%A1ln\%C3\%AD-stavsyst\%C3\%A9mu-intenzivn\%C3\%AD-p\%C3\%A9\%C4\%8De.pdf (dostęp: 1.06.2021)

https://zdopravy.cz/letecky-most-z-ciny-pokracuje-behem-prodlouzeneho-vikendu-prileti-seststroju-46637/ (dostęp: 1.06.2021)

https://www.idnes.cz/zpravy/domaci/nemocnice-prevoz-pacientu-covid-kornavirus.A210218_141533_domaci_remy (dostęp: 5.06.2021)

https://www.gov.pl/web/koronawirus/plany-na-jesien--strategia-walki-z-pandemia-koronawirusa (dostęp: 1.06.2021)

https://www.gov.pl/web/zdrowie/podwojenie-bazy-lozkowej-i-udogodnienia-dla-personelu-medycznego (dostęp: 1.06.2021)

https://www.gov.pl/web/zdrowie/covid---ewidencja-zakupow (dostęp: 29.05.2021)

https://www.politykazdrowotna.com/66189,lista-szpitali-tymczasowych-w-polsce (dostęp: 29.05.2021)

https://www.gov.pl/web/szczepimysie/mapa-punktow-szczepien\#Ministry of Healthcare website, accessed April 11, 2020

https://koronavirus.mzcr.cz/parlamentschvalil-opatreni-na-podporuplatcu-pojistneho (dostęp: 29.05.2021)

https://www.mzcr.cz/tiskove-centrum-mz/ministerstvo-zdravotnictvi-odeslalo-kompenzacnivyhlasku-do-sbirky-zakonu/ (dostęp: 29.05.2021)

https://www.mzcr.cz/tiskove-centrum-mz/ministerstvo-zdravotnictvi-odeslalo-kompenzacni-vyhlasku-do-sbirky-zakonu/ (dostęp: 29.05.2021)

https://www.mfcr.cz/cs/aktualne/tiskove-zpravy/2020/vlada-schvalila -novelu-zakona-o-statnim-37959 
Government Resolution No. 296, issued on March 23, 2020. https://apps. odok.cz/attachment/- /down/IHOABMZAP9TY (dostęp: 27.05.2021) https://www.gazetaprawna.pl/wiadomosci/artykuly/1497377,senat-gadomski-wydatki-w-tym-roku-na-walke-z-covid-19-wyniosa-okolo8-mld-zl.html (dostęp: 29.05.2021)

https://businessinsider.com.pl/firmy/dla-firm/fundusz-przeciwdzialania-covid-19-przedluzony-przez-premiera-morawieckiego/qt3npch (dostęp: 29.05.2021)

https://pulsmedycyny.pl/nfz-bedzie-dodatkowe-finansowanie-placowek-medycznych-996240

https://ourworldindata.org/covid-vaccinations (dostęp: 29.05.2021)

European Observatory of Health Systems and Policies, https://www. covid19healthsystem.org/mainpage.aspx

https://www.worldometers.info/coronavirus/?utm_campaign=homeAdUOA?Si\#main_table (dostęp: 29.05.2021)

Beyond Containment: Health systems responses to COVID-19 in the OECD, 2020, https://oecd.dam-broadcast.com/pm_7379_119_ 119689-ud5comtf84.pdf (dostęp: 5.06.2021)

\section{Copyright and License}

This article is published under the terms of the Creative Commons Attribution - NoDerivs (CC BY- ND 4.0) License http://creativecommons.org/licenses/by-nd/4.0/ 